\title{
Maria Karlberg \& Brigitte Mral: Heder och påverkan. Att analysera modern retorik. Stockholm: Natur \& Kultur, 1998
}

At interessen for retorik er vokset det seneste halve snes år fremgår tydeligt af mængden af bøger, som er udkommet. Tendensen har gjort sig gældende såvel i som uden for Skandinavien, og interessen gælder såvel retorikkens historie som dens anvendelse inden for forskellige former for tekstanalyse og ikke mindst pædagogik. I Sverige har det bl.a. resulteret i bøger fra Kurt Johannesson, Rudolf Rystedt (anmeldt i Hermes nr.13) og Peter Cassirer (anm. i nr. 20). Seneste tilskud kommer fra en gruppe forskere og studenter fra universitetet i Örebro i skriftserien Studier i kommunikation och medier. Bogen om "Hæder og påvirkning" er en "grundbok och en praktisk handledning för retorisk analys av olika typer av tal och texter", og den falder i to hoveddele: dels en "modell för retorikanalys", dels 8 korte analyseeksempler. Disse eksempler omhandler en McDonald's-reklame, Bushs tale ved starten af krigen mod Irak, prædikanten Ulf Ekman, Mona Sahlins forsvarstale, Bill Clintons forhold til civil religion, talkshows, filmen Independence Day og lederen af de svenske konservative Carl Bildts hjemmeside.

Den indledende model for retorikanalyse tilføjer ikke væsentligt nyt, hvis man har læst andre indføringer i retorikken; opbygningen er baseret på den klassiske retorik og gennemgår på 40 sider konteksten (genre, retorisk situation, publikum mm), disposition, overbevisning (ethos, logos, pathos), argumentation og stil med en afslutning om "Att formulera analysresultaten". Det siger næsten sig selv, at når man vil nå igennem disse emner på så lidt plads og samtidig i den grad anvender den klassiske retoriks begreber, så må der blive tale om en særdeles beskåret udgave af retorik. Det betyder også, at der ikke er tale om en egentlig model for, hvordan man $g \phi r$, når man skal analysere en tekst. Udtrykket "model" må her tolkes i betydningen "overordnet skitse", eller fortegnelse over områder, man bør søge oplysninger om andetsteds for at kunne gennemføre en analyse. For eksempel er det glimrende at påpege, at genre spiller en væsentlig rolle, men for det første forklares eller diskuteres det ikke, hvordan genren påvirker læsningen/læseren, for det andet bygges der på den klassiske retoriks tre genrer, og såvel i dette tilfælde som $\mathrm{i}$ andre $\mathrm{i}$ bogen må man spørge sig selv, om en så "trofast" analyse overhovedet får fat i de forskelle, som der er mellem forskellige former for tekster i vor verden. Havde man i stedet fokuseret på den retoriske funktion, ville man have kunnet give langt bedre vejledning til den studerende, som står over for et analyseobjekt. Ved at opfatte retorikken så traditionelt, bliver analyse i store dele af bogen et spørgsmål om at finde de rette kasser at putte de forskellige observationer ned i. Som de fleste andre lærere formodentlig også har oplevet, er det et stort problem at få studenterne til at indse, at det er vigtigere at kunne forklare et 
grebs eller en detaljes funktion end at bruge tiden på at diskutere, om det nu tilhører undergruppe X eller Y. Hvis retorik på denne måde bliver et spørgsmål om systematisering i klassifikationen, risikerer man at overse det, som er den moderne retoriks styrke, nemlig dens analyse af hvad der fungerer hvordan og evt. hvorfor. Dette problem vedrører også, hvorledes retorikken kan samarbejde med andre discipliner i en tekstanalyse, og dermed vedrører det bogens anden del, analyseeksemplerne.

Forfatternes ønske har været at anvende retorisk analyse på tekster "från vitt skilda områden", men 4 (eller 5) af teksterne tilhører kategorier, man traditionelt har analyseret retorisk, nemlig politiske tekster og taler og religiøse prædikener. Det er, logisk men måske paradoksalt nok, også disse tekster, som den retoriske analysemodel passer bedst på, selv om resultaterne ikke kan siges at være specielt opsigtsvækkende. Mest interessant er nok analysen af den nykristne Ulf Ekmans prædiken fra Livets Ord i Uppsala, selv om det i lige så høj grad skyldes hans meget specielle retorik. Ellers er der tale om traditionelle analyser af politiske tekster, som på grund af den ringe plads aldrig rigtig når til bunds. Her burde man have overvejet, om det ikke havde været mere pædagogisk med færre, men mere grundige analyser.

I de resterende analyser (af hhv. McDonald's-reklamen, talkshow og Independence Day) bliver det tydeligt, at en retorisk analyse af denne model ganske vist kan få interessante fakta frem, men aldrig vil kunne give en udtømmende analyse af sådanne tekster. Især i analysen af McDonald's reklame går det galt. Reklamen (som jeg ikke mindes at have set i en dansk udgave) indeholder et billede af to veninder og en lang tekst, som beskriver deres venskab og deres liv, med udgangspunkt i det faktum at de begge arbejder på McDonald's. Annoncen klassificeres som "corporate advertising" og som led i en opbygning af "corporate identity", men analysen ser kun modtagergruppen som (potentielle) konsumenter hos firmaet. Annoncen bliver dermed analyseret som retorisk strategi for at tiltrække sultne kunder, uden at reflektere over andre - og vigtigere - funktioner. Annoncen fors øger ganske vist at opbygge et positivt billede af koncernen, men den gør det også for at tiltrække arbejdskraft, og såvel annoncen som retorikken kan kun forstås, hvis man ser den som et modspil mod den stærkt negative omtale af koncernens arbejds- og lønpolitik, som er almindelig hos unge mennesker og i medierne. Man kan nok godt få folk til at spise i restauranterne, men hvis alle unge kunder er fulde af foragt for dem som arbejder der (i et såkaldt "McJob"), vil det være umuligt at tiltrække den lavtlønnede, unge og uuddannede arbejdskraft, som er en forudsætning for konkurrenceevnen. Samtidig er det også tvivlsomt, om firmaet i længere tid kan overleve et så negativt image m.h.t arbejdsforhold, uden at det smitter af på holdningen til produktet. Analysen holder sig, efter klassisk mønster, til en usammensat modtagergruppe og forudsætter at teksten har én 
funktion, og derved overser den helt nogle af de mest fundamentale forhold omkring det begreb, som den selv ifølge overskriften tager udgangspunkt i. Samtidig bliver det uklart hvad og i det hele taget om en sådan retorisk analyse kan bidrage med interessante resultater til en kommunikativ (public relations-) analyse.

Samme type af indvending kan man komme med til analysen af Independence Day: analysen holder sig til det retoriske, men postulerer at sige noget om helheden, nemlig filmen, uden at inddrage de metoder, som er udviklet til de forskellige udtryksformer. Derved kommer man i den situation, at den retoriske analyse tildeler sig selv hovedrollen. Det er en tendens, som genfindes i flere analyse- og teoriretninger: den egne model bliver dén, som subsummerer alle andre under sig. I dette tilfælde kan resultatet meget vel blive, at retorikken bliver forkastet af de studerende, der netop indser at den retoriske analyse ikke udgør en udtømmende analyse af de her præsenterede tekster. Et eksempel på, hvorledes man kan opretholde en retorisk vinkel og samtidig indplacere den i en bredere og mere generel (pragmatisk) ramme, kan man finde i fx Lennart Hellspong \& Per Ledin: Vägar genom texten. Handbok i brukstextanalys (anmeldt i Hermes nr.20), og såfremt man har muligheden for at perspektivere Heder och påverkan gennem netop denne type af analysemodeller, vil bogens analyser kunne bruges som udgangspunkt for en diskussion, bl.a. fordi originalteksterne i de fleste tilfælde er vedlagt. Alene vil den give et skævt billede af, hvad tekstanalyse er, og også af retorikkens relevans. 